\title{
IMPLEMENTASI BAURAN PEMASARAN KERAJINAN MISSE AKSESORIS PETAI CINA DALAM MENINGKATKAN PENJUALAN (STUDI KASUS DESA KARYA SAKTI )
}

\author{
Muhammad Saleh \\ Dosen Tetap Fakultas Ekonomi dan Bisnis Islam IAI Al-Azhaar \\ Lubuklinggau \\ muhammadsaleh@iai-al-azhaar.ac.id
}

\begin{abstract}
Abstrak: Pemasaran merupakan suatu proses sosial dan manajerial di mana individu dan kelompok mendapatkan kebutuhan dan keinginan mereka dengan menciptakan, menawarkan dan bertukar sesuatu yang bernilai satu sama lain. Definisi ini berdasarkan pada konsep inti: kebutuhan, keinginan dan permintaan; produk nilai, biaya dan kepuasan; pertukaran, transaksi, dan hubungan; pasar dan pemasaran serta pemasar. Kerajinan misse aksesoris di desa Karya Sakti merupakan kerajian tangan yang cukup unik tetapi masih banyak masyarakat yang belum tahu sehingga kesan yang timbul, kurang diminati di masyarakat dan membuat faktor penghambat dalam pemasarannya. Berdasarkan permasalahan ini menarik bagi peneliti untuk mengetahui melakukan penelitian sehingga mendapatkan hasil yang bermanfaat bagi pemilik kerajian, masyarakat dan penulis khususnya..

Adapun rumusan masalah dalam penelitian ini adalah: Bagaimana bauran pemasaran kerajinan misse aksesoris di desa Karya Sakti dan Apakah faktor penghambat bauran pemasaran kerajinan misse aksesoris dalam meningkatkan penjualan. Metode penelitian yang digunakan yaitu metode Dalam penelitian ini penulis menggunakan metode kualitatif. Data penulis peroleh dengan melakukan penelitian langsung ke lapangan (field reseach)

Kesimpulan bauran pemasaran melalui menggerakan potensi masyarakat, PKK memanfaatkan pemuka masyarakat, misalnya tokoh agama, adat, pendidikan termasuk pemuka wanita dengan memperhatikan kepentingan-kepentingan dalam mencari nafkah dan mengurus keluarganya. Adapun yang menghambat dalam bauran pemasaran dan penjualan kerajianan misse petai cina: Kurangnya jiwa seni kreatif masyarakat awam, Masyarakat Desa Karya Sakti lebih mementingkan kebutuhan rumah tangga, faktor ekonomi, kurangnya pengetahuan tentang kesenian, bahan baku sudah susah untuk di cari, penjualan hanya lewat bazar
\end{abstract}

Kata Kunci : Bauran, Pemasaran

\section{PENDAHULUAN}

Ada banyak pendapat di seputar pengertian dan ruang lingkup ekonomi Islam. Dawam Rahardjo, memilah istilah ekonomi Islam ke dalam tiga kemungkinan 
pemaknaan, pertama yang dimaksud ekonomi Islam adalah ilmu ekonomi yang berdasarkan nilai atau ajaran Islam. Kedua, yang dimaksud ekonomi Islam adalah sistem. Sistem menyangkut pengaturan yaitu pengaturan kegiatan ekonomi dalam satu masyarakat atau negara berdasarkan suatu cara atau metode tertentu. Sedangkan pilihan ketiga ekonomi Islam dalam pengertian perekonomian umat Islam. Dalam tulisan ini istilah ekonomi mencakup ketiganya dengan penekanan tersebut, yakni teori, sistem, dan kegiatan ekonomi umat Islam merupakan tiga pilar yang harus membentuk sebuah sinergi pemasaran merupakan suatu sistem keseluruhan dari kegiatan-kegiatan usaha yang ditunjukan untuk merencanakan, menentukan harga, mempromosikan, dan mendistribusikan barang dan jasa yang dapat merumuskan kebutuhan baik kepada pembeli yang ada maupun pembeli yang pontensial. ${ }^{1}$

Dunia pemasaran sering diidentikkan dengan dunia yang penuh janji manis namun belum tentu terbukti apakah produknya sesuai dengan apa yang telah yang dijanjikan. Inilah yang harus dibuktikan dalam suatu manajemen pemasaran syariah baik pada penjualan produk barang atau jasa. ${ }^{2}$ Dalam pemasaran syariah etika, nilainilai dan norma dijunjung tinggi. Hal inilah yang sering dilanggar dalam pemasaran. $^{3}$

Dalam syariah marketing, perusahan tidak hanya berorientasi pada keuntungan semata, namun turut pula berorientasi pada tujuan lainya yaitu keberkahan. Perpaduan konsep keuntungan dan keberkahan ini melahirkan konsep maslahah, yaitu suatu perusahaan syariah akan berorientasi pada pencapaian maslahah yang optimal. konsep keberkahan bagi sebagian pihak merupakan konsep yang abstrak karena secara keilmuan tidak dapat dibuktikan secara ilmiah, namun inilah salah satu konsep inti pada syariah marketing yang menjadi landasan pada satu perusahaan berorientasi syariah. ${ }^{4}$

\footnotetext{
$2010)$, h.1-5

${ }^{1}$ M. Nur Rianto Al Arif, Dasar-Dasar Pemasaran Bank Syariah: Teori dan Peraktik, (Jakarta januari h. $22-25$

${ }^{2}$ Hermawan Kertajaya dan Muhammad Syakir Sula, Syariah Marketing, ( Bandung: Mizan, 2006 ), 262.

${ }^{3}$ Bucharin Alam dan Doni juni Priansah, Manajemen Bisnis Syariah, (Bandung: Alfabeta 2009), h.

${ }^{4}$ Hermawan Kertajaya dan Muhammad Syakir Sula, Syariah Marketing.... h. 67-79
} 
Dari penjelasan di atas permasalahannya yang ada di kerajian misse aksesoris di desa Karya Sakti merupakan kerajian tangan yang cukup unik tetapi masih banyak masyarakat yang belum tahu sehingga kesan yang timbul, kurang diminati di masyarakat dan membuat faktor penghambat dalam pemasarannya. Berdasarkan permasalahan ini menarik bagi peneliti untuk mengetahui dan melakukan penelitian. judul "Implementasi Bauran Pemasaran Kerajinan Misse Aksesoris Petai Cina Dalam Meningkatkan Penjualan (Studi Kasus Desa Karya Sakti).

\section{METODE PENELITIAN}

1. Jenis dan Pendekatan Penelitian

Jenis penelitian yang digunakan dalam penelitian ini adalah jenis penelitian kualitatif. ${ }^{5}$ Adapun pendekatan penelitian yang digunakan deskriptif kualitatif. ${ }^{6}$

2. Subjek Penelitian

Dalam penelitian ini yang menjadi subjek penelitian yaitu karyawan yang menjual Upah Hari Kerja (HK) dan pembeli Upah Hari Kerja (HK) berjumlah 2 orang.

3. Teknik Pengumpulan Data

Dalam pengumpulan data, peneliti menggunakan beberapa metode yaitu: Observasi. ${ }^{7}$ Wawancara,.$^{8}$ Dokumentasi. ${ }^{9}$

4. Teknik Analisa Data

Teknik analisa data yang dilakukan dengan penelaahan, pengelompokan, sistematisasi, penafsiran, dan verivikasi data agar sebuah fenomena memiliki nilai sosial, akademis dan ilmiah. ${ }^{10}$

5. Teknik Pengujian Keabsahan Data

${ }^{5}$ J.R. Raco, Metode Penelitian Kualitatif Jenis, Karakteristik, dan Keunggulannya, (Jakarta: PT Grasindo, 2010), h. 9

${ }^{6}$ Lexy J. Moleong, Metodologi Penelitian Kualitatif..., h. 14-45

23

${ }^{7}$ V. Wiratna Sujarweni, Metodologi Penelitian, (Yogyakarta: Pustaka Baru Press, 2014), h.

${ }^{8}$ A. Muri Yusuf, Metode Penelitian Kuantitatif, Kualitatif, dan Penelitian Gabungan, (Jakarta: Kencana Prenada Media Group), h. 372

${ }^{9}$ V. Wiratna Sujarweni, Metodologi Penelitian ..., h. 23

${ }^{10}$ Sandu Siyoto dan M. Ali Sodik, Dasar Metodologi Penelitian, (Yogyakarta: Literasi Media Publishing, 2015), h. 109 
Untuk memperoleh data yang nilai keabsahannya mempunyai validitas maka peneliti melakukan usaha-usaha sebagai berikut: Perpanjangan kehadiran, Triangulasi. ${ }^{11}$

\section{HASIL PENELITIAN DAN PEMBAHASAN}

1. Hasil Penelitian

a. Bauran Pemasaran Kerajinan Misse Aksesoris Di Desa Karya Sakti

Berdasarkan hasil observasi; Kerajinan tangan Misse Aksesoris merupakan kerajinan tangan yang berasal dari petai cina untuk dijadikan aksesoris seperti kalung, gelang dan bros. Selain membangun dan mengembangkan potensi wilayah Desa Karya Sakti dampak pemberdayaan masyarakat melalui usaha kerajinan tangan Misse Aksesoris juga merubah pola pikir masyarakat ke arah yang lebih maju.

Wawancara yang dilakukan oleh Ibu PKK mengenai pemberdayaan oleh, Ibu Iis Rochani selaku Ketua PKK Desa Karya Sakti. ${ }^{12}$

"Masyarakat di Desa Karya Sakti masyarakat di wajibkan setiap rumah menanam batang petai cina, dan juga bagi Ibu-ibu desa karya sakti di wajibkan untuk bisa merangkai kalung petai cina."

Berdasarkan observasi pada hari kamis tanggal 23 Mei 2020 peneliti dapatkan dilapangan, untuk melakukan pemberdayaan masyarakat tentunnya untuk memajukan sebuah desa peran penting yang dilakukan ialah seorang ketua untuk mengajak warganya saling membantu kerjasama baik dari segi fisik dan non fisik, seperti yang dilakukan oleh Desa Karya sakti dalam membangun sebuah karya kerajianan tangan melalui kerajinan misse aksesoris.

Adapun bahan-bahan dalam pembuatan kerajinan misse aksesoris petai cina, oleh Rizka Gear Aprianto. ${ }^{13}$

"Buah petai cina atau melanding yang sudah tua, benang jait yang tidak mudah putus, jarum jahit untuk merangkainya dan pernis untuk mengkilatkan warna alamnya."

\footnotetext{
${ }^{11}$ Lexy J. Moleong, Metodologi Penelitian Kualitatif..., h. 332

${ }^{12}$ Wawancara, Ibu Iis Rochani sebagai Ketua PKK Desa Karya Sakti, Pada hari Sabtu 09 Mei 2020, Jam 13.00.

${ }^{13}$ Wawancara, Rizka Gear Aprianto sebagai Pembuat Kerajinan Misse Petai Cina Desa Karya Sakti, Pada hari Sabtu 09 Mei 2020, Jam 13.25.
} 
Berdasarkan observasi pada hari kamis tanggal 23 Mei 2020 peneliti dapatkan dilapangan, dengan berbagai macam bahan yang ada untuk bisa dijadikan aksesoris tentunya di buat sebagus mungkin dan menarik hati pembeli nantinya agar puas ketika nanti konsumen membeli aksesoris tersebut, dan juga haruslah bisa untuk mempromosikannya.

Adapun wawancara mengenai harga yang di jualkan kerajinan misse aksesoris, oleh Ibu Lilis Suryati. ${ }^{14}$

“Aksesoris kalung berkisar Rp 80.000-170.000, Bros Rp 35.000- Rp 80.000.”

Berdasarkan observasi pada hari kamis tanggal 23 Mei 2020 peneliti dapatkan dilapangan, dengan harga yang terjangkau oleh masyarakat tentunya minat untuk membeli akan banyak, dengan cara mempromosikan tentunya dengan variasi yang unik dengan begitu masyarakat akan membeli aksesoris petai cina.

Wawancara selanjutnya penjualan kerajinan misse aksesoris petai cina tidak hanya di sekitar lingkungan, seperti yang di ungkapkan oleh, Ibu Nur Janah. ${ }^{15}$

"Pemasarannya alhamdullilah sudah ke luar pulau Sumatera, ke kota Jakarta, Padang, bahkan sudah sampai Malaysia. bahkan pemasarannya di bantu oleh bunda novi selaku ketua PKK kabupaten Musirawas, jika beliau ada pertemuan di luar kota selalu membawa aksesoris kami dan juga oleh dinas Perindag, dinas Koperasi, dinas Perpajakan dan BUMN juga membantu untuk pemasarannya.

Berdasarkan observasi pada hari kamis tanggal 23 Mei 2020 peneliti dapatkan dilapangan, dalam sebuah penjualan atau memasarkan sebuah produk atau barang tentunya tidak mudah untuk menawarkan terhadap konsumen, karena konsumen melihat dari segi bagus atau jeleknya murah atau mahal yang akan di jual. Karena kebanyakan konsumen memilih barang yang bagus harga yang murah.

Sementara itu wawancara strategi distribusi kerajinan misse aksesoris petai cina di Desa Karya Sakti oleh, Ibu Yuni Rasilah. ${ }^{16}$

"Dikarenakan masyarakat desa tidak terlalu menyukai aksesoris kami selaku tim produksi tidak memaksa untuk membeli, tetapi kami mengajarkan kepada ibu-

\footnotetext{
${ }^{14}$ Wawancara, Ibu Lilis Suryati sebagai Pembuat Kerajinan Misse Petai Cina Desa Karya Sakti, Pada hari Sabtu 09 Mei 2020, Jam 13.25.

${ }^{15}$ Wawancara, Ibu Nur Janah sebagai Pemasaran Kerajinan Misse Petai Cina Desa Karya Sakti, Pada hari Sabtu 09 Mei 2020, Jam 14.30.

${ }^{16}$ Wawancara, Ibu Yani Rasilah sebagai Finishing Kerajinan Misse Petai Cina Desa Karya Sakti, Pada hari Sabtu 09 Mei 2020, Jam 14.25
} 
ibu untuk bisa menghasilkan sendiri aksesoris dari petai cina sebagai bentuk pemasaran agar masyarakat luas mengenal hasil karya kami."

Berdasarkan observasi pada hari kamis tanggal 23 Mei 2020 peneliti dapatkan dilapangan, kurangnya minat dalam membeli produk sendiri di masyarakat menjadikan bahan pertanyaan karena Desa tersebut membuat aksesoris misse petai cina, setidaknya untuk menarikk daya perhatian agar apa yang menjadi kerajinan tangan tersebut membuahkan hasil dan tentunya semakin memperkenalkan ke desadesa lain.

Kemudian dalam wawancara selanjutnya mengenai pengambilan keuntungan dalam menjual serta kesesuaian dalam Syariah Islam yang di ungkapkan oleh, Ibu Maqfirotun Naimah. ${ }^{17}$

"Misal untuk satu kalung dengan harga 100.000 maka hasilnya dibagi: pertama dipotong untuk bahan baku sebesar 25.000, kemudian upah merangkai kalung 50.000, dan kami mendapatkan keuntungan sebesar 25.000 dari satu kalung tersebut, serta kami sudah sesuai dengan syariah dari kami menawarkan produk, membuat dan mendapatkan sebuah hasil bila kerajinan misse petai cina nantinya bila laku"

Berdasarkan observasi pada hari kamis tanggal 23 Mei 2020 peneliti dapatkan dilapangan, dengan kejelasan yang sudah disepakati maka tidak terjadi sebuah keselisihan dan dalam syariah sudah diajarkan seperti Rosulullah mengajarkan untuk jujur, adil, amanah, dan dapat di percaya, serta dalam penjualan tidak memakan riba atau merugikan dengan orang lain.

b. Faktor Penghambat Bauran Pemasaran Kerajinan Misse Aksesoris Dalam Meningkatkan Penjualan

Sudah menjadi suatu keniscayaan bahwa setiap usaha/perusahaan dalam menjalankan kegiatan pemasaran dan kebijakan-kebijakan yang telah dirumuskan pastilah tidak selalu sesuai dengan apa yang diharapkan. Di sisi lain pasti selalu ada halangan dan rintangan serta badai yang menerpa. Hal demikian pulalah yang nampaknya juga terdapat pada kegiatan kerajinan Misse Aksesoris di Desa Karya Sakti.

${ }^{17}$ Wawancara, Ibu Maqfirotun Naimah sebagai Pembuat Kerajinan Misse Petai Cina Desa Karya Sakti, Pada hari Sabtu 09 Mei 2020, Jam 13.00. 
Adapun wawancara permasalahan kerajinan Misse Aksesoris yang di Desa Karya Sakti yang di ungkapkan oleh, Ibu Iis Rochani. ${ }^{18}$

"Ada beberapa permasalahan pada kerjinan Misse Aksesoris di Desa Karya Sakti: 1) Kurangnya jiwa seni kreatif masyarakat awam, 2) Masyarakat Desa Karya Sakti lebih mementingkan kebutuhan rumah tangga, 3) Faktor ekonomi, 4) kurangnya pengetahuan tentang kesenian, 5) Bahan baku sudah susah untuk di cari, 5) Penjualan hanya lewat bazar."

Berdasarkan observasi pada hari kamis tanggal 23 Mei 2020 peneliti dapatkan dilapangan, tentunya dalam sebuah perusahaan setiap membuka usaha pastinya akan mengalami sebuah masalah, sebab masalah tersebut untuk di jadikan tolak ukur untuk sebuah keberhasilan sebuah usaha tersebut. Dari sebuah masalah akan di perbaiki dengan begitu akan menemukan titik suatu permasalahan dan solusinya, jelas peran dari Ketua PKK dan karyawan harus cepat dan tanggap dalam menghadapi sebuah persoalan tersebut dan di bantu dengan masyarakat sekitar untuk memajukan karya kerajinan Misse Petai Cina yang ada di Desa Karya Sakti.

Kemudian dari itu terdapat kendala terhadap penjualan, seperti wawancara yang di ungkapkan oleh, Ibu Nur Janah. ${ }^{19}$

"Permasalahannya dalam penjualan online di desa kami sinyalnya yang tidak mendukung, Kurangnya minat di bidang seni, Kendala dipemasaran di Desa warga masyarkat masih kurang percaya diri dan untuk menghasilkan aksesoris sebagian harga saja tidak mau, lingkungan dan gaya hidup sekitar yang tidak sesuai dengan gaya/mode misse, hanya serasi digunakan oleh orang-orang Kota."

Berdasarkan observasi pada hari kamis tanggal 23 Mei 2020 peneliti dapatkan dilapangan, masalah dalam penjualan sering terjadi kalau produk pasti tentang harga, apalagi seperti di saat sekarang ini ingin produk yang bagus dengan nilai harga yang murah. Tentu dalam proses dalam pembuatan yang lumayan panjang, harga dan produknya pun sesuai. Masalah selain harga, minat, tentunya masih banyak faktor lain itu sudah resiko usaha, kembali lagi dalam sebuah memanage untuk berjalannya sebuah usaha, yang kurang minat supaya minat, harga jual, promosi ke Desa-desa lain, dan bahkan ke luar Kota.

${ }^{18}$ Wawancara, Ibu Iis Rochani sebagai Ketua PKK Desa Karya Sakti, Pada hari Sabtu 09 Mei 2020, Jam 13.00.

${ }^{19}$ Wawancara, Ibu Nur Janah sebagai Pemasaran Kerajinan Misse Petai Cina Desa Karya Sakti, Pada hari Sabtu 09 Mei 2020, Jam 14.30. 
Kemudian wawancara selanjutnya mengenai cara meningkatkan pembinaan, pengelolaan, dan pengembangan program usaha peningkatan kerajinan misse aksesoris petai cina di Desa Karya Sakti, oleh Ibu Iis Rochani. ${ }^{20}$

"Dengan mendatangkan Dinas Perindag untuk membimbing kami, mengadakan sosialis ke ibu-ibu yang punya jiwa seni kreatif, dan kami bimbing agar dapat menghasilkan suatu kerajinan dari petai cina."

Berdasarkan observasi pada hari kamis tanggal 23 Mei 2020 peneliti dapatkan dilapangan, untuk mengembangkan program usaha kerajinan misse aksesoris perlu bantuan dengan mendatangkan Dinas-dinas terkait yang ada di Dessa Karya Sakti untuk memperkenalkan kepada masyarakat dengan diadakan pertemuan-pertemuan dan mengadakan kegiatan pelatihan khusus.

Adapun wawancara mengenai strategi pengelolaan kerajinan misse aksesoris dalam meningkatkan penjualan kerajinan misse aksesoris petai cina di Desa Karya Sakti, yang di ungkapkan oleh Ibu Eni. ${ }^{21}$

"Tidak strategi karena masyarakat kurang percaya diri di tambah lagi untuk memakai aksesoris kurang trand mengikuti zaman sekarang"

Berdasarkan observasi pada hari kamis tanggal 23 Mei 2020 peneliti dapatkan dilapangan, tidak tahunya keanekaragaman hayati yang di miliki di Desa tersebut sangat perihatin karena itu merupakan kerajinan dari alami tentunya tidak meninggalkan budaya-budaya atau aksesoris seperti zaman dahulu. Tentunya bisa menambah nilai tersendiri bila masyarakatnya minat dengan produk dari alam, tidak hanya mengikuti zaman akan lupa dengan budaya terdahulu, peran seorang ketua PKK desa Karya Sakti dan seluruh elemen masyarakat harus menjalin kerja sama agar banyak peminat dan bahkan bisa membanggakan produk pembuatan sendiri.

Wawancara berikutnya mengengai minat agar masyarakat minat untuk membeli Misse Aksesoris Petai Cina, yang diungkapkan oleh Ibu Sularti. ${ }^{22}$

\footnotetext{
${ }^{20}$ Wawancara, Ibu Iis Rochani sebagai Ketua PKK Desa Karya Sakti, Pada hari Sabtu 09 Mei 2020, Jam 13.00.

${ }^{21}$ Wawancara, Ibu Eni sebagai pembuat kerajinan misse aksesoris petai cina, Pada hari Sabtu 09 Mei 2020, Jam 15.00.

${ }^{22}$ Wawancara, Ibu Sularti sebagai pembuat kerajinan misse aksesoris petai cina, Pada hari Sabtu 09 Mei 2020, Jam 16.00.
} 
"Menambah model baru yang menarik, Mempercantik tampilan misse, meningkatkan kualitas misse, memberi diskon."

Berdasarkan observasi pada hari kamis tanggal 23 Mei 2020 peneliti dapatkan dilapangan, setelah pembuatan sebuah produk tentunya agar masyarakat atau konsumen untuk membeli dengan hasil tersebut, dengan cara mempromosikan dan mengambil hati terhadap konsumen.

Wawancaranya selanjutnya, menghadapi masalah permasalahan mengenai konsumen yang akan membeli Misse Aksesoris Petai Cina, oleh Yani Arsilah ${ }^{23}$

"Meyakini konsumen bahwa bahan di jamin bagus, dengan ramah dan sabar melayani."

Berdasarkan observasi pada hari kamis tanggal 23 Mei 2020 peneliti dapatkan dilapangan, dalam menghadapi konsumen akan mengalami berbagai macam tentunya dalam menawarkan produk harus ramah, murah senyum, tekun dan sebisa mungkin mengambil hati pembeli tersebut agar membeli. Bahwa kerajinan misse petai cina itu layak untuk di pasarkan dan bahkan untuk persaingan aksesoris lainya yang ada di luar Desa maupun di dalam Desa.

Wawancara dengan tujuan diadakannya Kerajinan Misse Aksesoris Petai Cina di Desa Karya Sakti, yang di ungkapkan oleh, Ibu Iis Rochani. ${ }^{24}$

"Untuk memanfaatkan hasil alam yang ada di desa kami yang jarang masyarakat menggunakannya, Untuk meningkatkan perekonomian keluarga bagi ibu-ibu yang ada di rumah, untuk meningkatkan tarap penghasilan karyawan, untuk lebih dikenal lagi Desa Karya Sakti dengan ciri khas aksesoris petai cina.

Berdasarkan observasi pada hari kamis tanggal 23 Mei 2020 peneliti dapatkan dilapangan, dengan adanya program kerajinan misse petai cina akan mengangkat budaya serta produk alami dari bumi yang ada di Desa Karya Sakti dengan begitu desa tersebut bila dalam pembuatan nya terus menerus tidak ada kata tidak mungkin bisa ikut bersaing dengan aksesoris-aksesoris zaman sekarang. Tentunya dari

${ }^{23}$ Wawancara, Ibu Yani Arsilah sebagai Finishing kerajinan misse aksesoris petai cina, Pada hari Sabtu 09 Mei 2020, Jam 16.25.

${ }^{24}$ Wawancara, Ibu Iis Rochani sebagai Ketua PKK Desa Karya Sakti, Pada hari Sabtu 09 Mei 2020, Jam 13.00. 
Ketua, karyawan serta elem masyarat yang mendukung dan menggunakan aksesoris tersebut.

Dari hasil wawancara dan observasi diatas dapat disimpulkan, dalam setiap usaha mengalami masalah, penghambat dan berbagai macam kendala lainnya. Peran dari Ketua PKK, karyawan serta masyarakat di Desa Karya Sakti harus kompak dan bersama-sama mengatasi demi kemajuan desa tersebut.

2. Pembahasan

a. Bauran Pemasaran Kerajinan Misse Aksesoris Di Desa Karya Sakti

Pada bauran pemasaran mengenai product, price, place, dan promotion, atau yang lebih sering dikenal sebagai $4 \mathrm{P}$ in marketing. Penggunaan konsep marketing mix sudah dianggap sebagai sebuah keharusan. Karena itu, tidak jarang orang memandang pemasaran hanya sebatas marketing mix. Dengan menganggap bahwa pemasaran hanya sebatas marketing mix atau bauran pemasaran. Produk (Product), Harga (Price), Distribusi/ Lokasi (Place), Promosi (Promotion). ${ }^{25}$

Dalam konsep pemasaran syariah ada sembilan elemen inti yang menjadi strategi jitu dalam pemasaran syariah. Sembilan elemen inti tersebut terangkum dalam tiga komponen yaitu strategi pemasaran syariah untuk memenangkan pikiran (mind share), taktik pemasaran suyariah untuk memenangkan pasar (market share) value pemasaran syariah (market value) untuk memenagngkan hati (heart share).

Produk merupakan bauran pemasaran yang paling mendasar. Produk tidak hanya obyek fisik, tetapi merupakan seperangkat manfaat atau nilai yang dapat memuaskan kebutuhan pelanggan, baik secara fungsional maupun manfaat secara psikologis dan sosial. Produk yang ditawarkan Kerajinan Misse Petai Cina di Desa Karya Sakti, dengan dibantu karyawan yang berjuamlah dari 10 orang dan terbagi masing-masing tugasnya, adapun tujuannya ialah untuk memanfaatkan hasil alam yang ada di desa kami yang jarang masyarakat menggunakannya, Untuk meningkatkan perekonomian keluarga bagi ibu-ibu yang ada di rumah, untuk meningkatkan tarap penghasilan karyawan, untuk lebih dikenal lagi Desa Karya Sakti dengan ciri khas aksesoris petai cina. Seperti yang kita ketahui bahwa saat ini

${ }^{25}$ Thotik Gunara, Utus Sudibyo, Marketing Muhammad SAW...., h. 47-51. 
budaya dengan hasil bumi sendiri sepertinya sudah langka kalah bersaing dengan gaya/trend zaman sekarang.

Maka dari itu bauran pemasaran untuk memberdayaan masyarakat berupaya upaya untuk meningkatkan harkat dan martabat lapisan masyarakat yang dalam kondisi sekarang tidak mampu melepaskan diri dari perangkap kemiskinan dan keterbelakangan melaui Program Kesejahteraan Keluarga (PKK) di Desa Karya Sakti yang berperan dalam memajukan kesejahteraan Ekonomi Masyarakat peneliti menemukan bahwa masih Kurangnya jiwa seni kreatif masyarakat awam, Masyarakat Desa Karya Sakti lebih mementingkan kebutuhan rumah tangga, faktor ekonomi, kurangnya pengetahuan tentang kesenian, bahan baku sudah susah untuk di cari. Peran lain seperti pengembangan PKK dari sisi pembinaan dengan adanya pelatihan, pemasaran sudah berjalan dengan baik.

PKK menjadi gerakan untuk membantu dan mendukung program- program pemerintah dengan mendata beberapa aspek yang diperlukan seperti data warga dan kegiatan masyarakat. PKK fokus dalam memberdayakan ekonomi warga yang kurang mampu dengan cara membantu ekonomi masyarakat terutama membantu Ibu-ibu rumah tangga. Program kerja PKK berorientasi pada praktis, artinya PKK bergerak pada aksi-aksi nyata memberdayakan dan memihak kaum perempuan. Lebih dari itu, PKK mempunyai andil besar dalam mensukseskan lomba antar kelurahan.

Berdasarkan hasil penelitian, bahwasanya kesejahteraan dalam bauran pemasaran masyarakat bukan hanya untuk minat membeli akan tetapi untuk lebih menyukai produk pembuatan sendiri dan bahkan dari bahan alami, diharapkan dengan diadakannya penyuluhan, pembinaan, baik dari Dinas Perindak, Dinas terkait yang ada di desa Karya Sakti untuk membantu dan mendorong minat kerajinan misse petai cina. Dalam Al-Qur'an juga dijelaskan untuk saling menolong demi kemajuan Desa dan membatu untuk mencari nafkah terutama pada Ibu-ibu rumah tangga untuk membantu para suami menambah hasil kerjaa dari suaminya. Seperti dalam Al-Qur'an, Al-Maidah, 2:

Artinya: dan tolong-menolonglah kamu dalam (mengerjakan) kebajikan dan takwa, dan jangan tolong-menolong dalam berbuat dosa dan pelanggaran. dan 
bertakwalah kamu kepada Allah, Sesungguhnya Allah Amat berat siksa-Nya. (Q.S. Al-Maidah: 2)

Berdasarkah hasil penelitian, untuk meningkatkan bauran pemasaran kerajinan misse petai cina di Desa Karya Sakti dilakukan kader pemberdayaan yang berjumlah kader pemberdayaan dan kesejahteraan sebanyak 10 orang. Dalam kegiatan yang dilakukan dalam meningkatkan kerajianan misse petai cina di Desa Karya Sakti diadakannya pelatihan, pengemabangan, keterampilan kerja. Selain dari itu, PKK juga mendukung sepenuhnya pelatihan atau kursus untuk membuat berbagai kerajinan tangan, kerajinan ini yang dapat membantu untuk meningkatkan pendapatan keluarga.

b. Faktor Penghambat Bauran Pemasaran Kerajinan Misse Aksesoris Dalam Meningkatkan Penjualan

Selain memiliki potensi alam dan masyarakat sebagai pendukung kegiatan yang dilaksanakan kerajinan misse aksesoris petai cina dalam memberdayakan masyarakat Desa Karya Sakti, dalam kenyataannya juga memiliki berbagai faktor penghambat yang sering menghambat dalam proses kegiatan ini. Faktor penghambat ini berasal dari alam dan dari sumber daya manusianya.

Terdapat beberapa masalah yang pada bauran pemasaran di Desa karya Sakti: Kurangnya jiwa seni kreatif masyarakat awam, Masyarakat Desa Karya Sakti lebih mementingkan kebutuhan rumah tangga, Faktor ekonomi, kurangnya pengetahuan tentang kesenian, Bahan baku sudah susah untuk di cari, Penjualan hanya lewat bazar." Dalam segi penjualannya juga terdapat masalah: Permasalahannya dalam penjualan online di desa kami sinyalnya yang tidak mendukung, Kurangnya minat di bidang seni, Kendala dipemasaran di Desa warga masyarkat masih kurang percaya diri dan untuk menghasilkan aksesoris sebagian harga saja tidak mau, lingkungan dan gaya hidup sekitar yang tidak sesuai dengan gaya/mode misse, hanya serasi digunakan oleh orang-orang Kota."

Dari hasil penelitian serta pembahasan yang di lakukan maka dari berbagai kendala yang dihadapi dalam pemberdayaan masyarakat melalui usaha kerajinan misse petai cina terhadap peningkatan ekonomi keluarga di Desa Karya Sakti. Sumber daya masyarakatnya perlu diberikan tambahan ilmu teknologi agar dengan 
berkembangnya ilmu teknologi nantinya mereka akan mampu menghadapi zaman yang modern seperti saat ini terutama dalam hal pemasaran. Dalam Islam sangat memperhatikan pelayanan yang baik kepada nasabah. Dalam islam telah diperintahakan dengan perintah yang ekspresif agar kaum muslimin bersifat simpatik, lembut, dan sopan.

\section{KESIMPULAN DAN SARAN}

Berdasarkan bauran pemasaran Desa Karya Sakti, dalam menggerakan potensi masyarakat, PKK memanfaatkan pemuka masyarakat, misalnya tokoh agama, adat, pendidikan termasuk pemuka wanita dengan memperhatikan kepentingan-kepentingan dalam mencari nafkah dan mengurus keluarganya. dengan meningkatkan pembinaan, pengelolaan, dan pengembangan PKK. Dalam program ini, PKK harus dapat menggali potensi yang terdapat di masyarakat Desa Karya Sakti. Oleh karena itu, kader-kader PKK yang tergabung dituntut untuk bersifat kreatif dan inovatif. Mereka juga harus jeli dalam melihat potensi dan sumber daya yang terdapat di masyarakat setempat. Misalnya dengan memberi pelatihan, kursus, dan kegiatan-kegiatan lain yang dapat meningkatkan pendapatan keluarga.

Adapun yang menghambat dalam bauran pemasaran dan penjualan kerajianan misse petai cina: Dari segi produk, kurangnya pengetahuan di bidang seni, parian produk masih sedikit. Dari segi harga, masih bingung dalam pentuan harga karena masih terbatasnya bahan baku. Dari segi tempat, tidak strategisnya tempat karena masih terletak di daerah pedesaan sedangkan konsumennya rata-rata orang-orang kota. Dari segi promosi, belum adanya aliran internet yang mendukung dan pengetahuan tentang pemasaran secara online sehingga pemasaran dan penjualan baru fokus ketika ada bazar.

\section{DAFTAR PUSTAKA}

Al Arif M Nur Rianto, Dasar-Dasar Pemasaran Bank Syariah: Teori dan Peraktik, Jakarta: Alfabeta, 2010.

Alam Bucharin dan juni Priansah Doni, Manajemen Bisnis Syariah, Bandung: Alfabeta 2009. 
Amirullah, Imam Hardjanto, Pengantar Bisnis, Yogyakarta: Graha Ilmu, 2005.

Alma, Buchari, Etika Bisnis Syari'ah, Bandung: Alfabeta, 2014.

Gunara, Thotik, Utus Sudibyo, Marketing Muhammad Saw., Bandung: Madani Prima, 2008.

Ismail Yusanto, Muhammad, Karebet Widjajakusuma Muhammad, Menggas Bisnis Islami, Jakarta: Gema Insani, cet. ke-7, 2008.

Kertajaya, Hermawan dan Sula Syakir Muhammad, Syariah Marketing, Bandung: Mizan, 2006.

Kotler Philip, Susanto A.B., Manajemen Pemasaran: Analisis, Perencanaan, Implementasi dan Pengendalian Jilid 1, Jakarta: Salemba Empat, 1999.

Marius P. Angipura, Dasar-dasar Pemasaran (Jakarta: Raja Gofindo Persada, 2002.

Moleong J, Lexy, Metode Penelitian Kualitatif, Bandung: PT. Remaja Rosda Karya, 2014.

Nitisemito, Alex S, Marketing, Jakarta: Ghalia Indonesia, 1981.

Notoadmodjo, Soekidjo, Metodologi Penelitian Kesehatan, Jakarta: Rineka Cipta, 2012.

Sula Syakir, Muhammad, Asuransi Syariah Konsep dan Sistem Operasional, Jakarta: Gema Insani, 2004.

Suryana, Agus, strategi Pemasaran, Jakarta: EDSA Makota, 2007.

Simamora, Bilson, Memenangkan Pasar Dengan Pemasaran Efektif dan Profitable, Jakarta : PT. Gramedia Pustaka Utama, 2003.

Sugiyono, Metode Penelitian Kombinasi (Mixed Methods), Bandung: Alfabeta, 2013.

Tjiptono, Fandi, Pemasaran Jasa, Malang: Bayu Media Publisihing, 2006.

Tohar M., Membuka Usaha Kecil, Yogyakarta: Kanisius, 2000. 